\title{
Grundtvig and Germany
}

\author{
By Götz Harbsmeier
}

\section{Introduction}

By comparison with a general topic like "Kierkegaard and Germany" or "Shakespeare and Germany" or "Selma Lagerlöf and Germany" there is surprisingly little one can say about a direct influence of Grundtvig on developments in Germany. Grundtvig may be known as the father of Colleges of Further Education, but that is just about as far as it goes. One cannot even say that Grundtvig was the father of the Colleges of Further Education in Germany, if one thereby wishes to imply that their development in Germany was inspired by Grundtvig's ideas.

In Germany, Grundtvig is almost only known as a Danish Nationalist, as one of the forerunners of racialist thought as it developed in fascist Germany under the name "Völkischer Beobachter". Of course, this nationalistic interpretation of Grundtvig is quite off the mark. So it is not surprising that the German Colleges of Further Education after the last world war did not draw real inspiration from Grundtvig, and this applies both to the generally cultural and the specifically religious or theological areas.

Grundtvig's writings on the Folk High School have been translated into German after the first World War, but it is quite clear that they were not adequately interpreted: the translation was inadequate and it did not find wide publicity. So even today Grundtvig is most well-known as the crown-witness of the ideology of the fair-haired, blue-eyed Germanic race of the north.

Grundtvig's poetry, his popular songs and church-songs have remained almost completely unknown. Only recently have there been some useful translations by Görnandt.

As a theologian, Grundtvig himself is only known through Kierkegaard's ironic rejection of his position. (In The Moment, and in Kierkegaard's diaries). There are no translations of Grundtvig's 
own theological writings. (See however my own book which has just appeared, a hundred years after Grundtvig's death).

We sadly conclude that Grundtvig is currently known in Germany only either through a nationalistic misinterpretation or through Kierkegaard's ironic criticisms. Consequently, he is highly suspect among theologians and among educationalists he is only accepted with many qualifications, while his writings remain largely unknown. Only in most recent times - perhaps owing to tourist's experiences! - have educationalists shown a greater interest in Grundtvig.

One might consider, that the foregoing remarks really exhaust the topic which I have been asked to talk about: there is no important news about Grundtvig to report from Germany.

But quite another question arises in this connection: what could and should Grundtvig mean for Germany in the areas of the humanities, education, art, politics, and theology? It is to this latter question that I want to give a few preliminary answers in what follows. Grundtvig's thought and activities covered an enormously wide range as emerges from Dr. Thaning's talk at this conference, and I hope I may be excused as a theologian in paying special attention to the theological importance of Grundtvig for the current situation in Germany. But it is an endearing characteristic of Grundtvig's thought that his theological reflections make crucial reference to the so-called profane side in the life and work of Grundtvig. I think I shall be acting quite in the spirit of Grundtvig himself if I constantly keep track of the "profanely human" relevance of Grundtvig's theological reflections.

\section{Grundtvig's discovery of humanity in the "living rord"}

The basic question for Grundtvig concerns the problem of man rather than the paradox of God. In this Grundtvig is not only opposed to his contemporary Kierkegaard but also to the general direction of German (protestant) theology and philosophy at least since the reformation and especially since the beginnings of dialectical theology, as it started with Karl Barth, who in turn was under the influence of Kierkegaard.

The history of German sermons also shows this starting from the paradoxality of God, the start from the "quite different" God, who manifests himself by hiding himself. There is no greater sin 
for the early and also for the later Barth, than to start theologically with man and not with God.

The objection of Barth's against Bultmann as well as Gogarten was, that the latter theologians started with man and not with God and Christ. It was in this that Barth saw the latent atheism in these writers. It is through this opposition that the initial cooperation between Barth, Bultmann and Gogarten was broken up.

It would, however, be quite wrong to equate Grundtvig's approach with the very different conception of Bultmann and Gogarten. In fact, Grundtvig does not start out with man, although it may look at first sight as if he does. Really, man only becomes a puzzle for Grundtvig to the extent that man recognizes the Godhood of God, and the clarity of God. Man only becomes fundamentally problematical to the extent that God is thought of by man as both creator, support, and as the Saviour of men.

The conceptions of Bultmann and Gogarten are fundamentally determined by hermeneutic considerations. They are basically concerned with the problem, how can the gospel be explained to men today? But Grundtvig is fundamentally not after a solution of that problem, which has come to be known as the hermeneutic one. $\mathrm{He}$ is not concerned with Bultmann's "Faith and Understanding" but with a quite unprogrammatic discovery which Grundtvig happened to make. Grundtvig did not hit upon this discovery in the process of a systematic program of research or in the process of a specific inquiry. Rather, Grundtvig made this discovery in a highly personal attempt to solve his inner problems, in his meeting other men, in his ordinary daily life. Grundtvig is not at all a detached, academic, philosophically-minded, speculative kind of man who keeps at a distance from life. Above all he is orientated towards experience and daily observation, and first of all he seems to me to be a poet, though no doubt Grundtvig himself preferred to see himself as a historian. Grundtvig thinks about a problem until he has found a clear, cogent and poetic way of stating the solution to his problem, he does not strive for conceptual precision. He is not a speculative thinker, but rather a naive realist, but as such he incessantly researches, reads and writes, is possessed by an enormous capacity to grasp and remember arguments and facts.

Grundtvig's profound discovery is the word of man, the viva vox living speech of man. That has precious little to do with the 
wisdom of books, it has everything to do with the experience of everyday life, the meeting with women and the open talk. It is impossible to call this a linguistic discovery, or even a contribution to linguistics. Nevertheless, in some not easily definable way, this discovery seems to me to be of crucial significance for a science of language which sets out to do more than define grammatical and semantic platitudes precisely. (By saying that I do not criticize current theories of grammar and semantics that go by the name of linguistics. I merely wish to put them in their place).

Grundtvig's discovery of the viva vox is the discovery of the fundamentally human side of human speech, the way it differs from all non-human parts of the creation. (One might say that the clear tendency in modern linguistics is precisely the opposite: they study just those aspects of human language that can be mastered, that form an impersonal "competence" which a computer might try to reconstruct). Grundtvig's discovery has not to do with an "objective" fact about the speech on the lips of men. What he discovered is not on the surface of objective facts, it is the subject of everyday experience, not of scientific experiments. It is the honesty, the love, and the strength in the speech of men. These three are present in speech not in an objective way, but they are the real human stuff that makes up human speech. All men have a sense for that. All men are able to experience it, in fact they desperately need to feel it: they have a sixth sense for it. They all know, how important "love" is in speech, how much honesty in speech convinces and how much power can reside in speech. Everyone knows about the destructive power of the opposite: the hateful speech, the lie and the arbitrariness of human speech. We all know of the emptiness and tediousness of human speech without a trace of love, honesty and power. These three, love, honesty, and power constitute what Grundtvig calls the underivably, unmistakably wonderful and miraculous in the spoken word. It is in that the humanness of man resides. (The opposite is the inhuman in man).

For Grundtvig that is not something divine in man, but it is a human thing which comes from God. Man is dust and he does not cease to be dust when he is inspired by the spirit of God, and that inspiration of God manifests itself in the love, the power and the honesty of speech. 
We have the word of love, of power and of honesty in common with God, not in order that we may be like gods, but because God has created and called man to a union with him.

It is this, Grundtvig's thought, that does not start with man but with God. Grundtvig neither wishes to nor can talk about God without seeing man as a creation of God. And the puzzle and paradox is not created by the fact, that man is God's creation but that man revolts against being God's creation although he obviously is God's creation in the honesty, the love and the power of the creating word of God.

Grundtvig cannot speak truly, lovingly and effectively of man without understanding man as a creature of God.

In the German theology of Existentialism things are quite different. According to that way of thinking one can and must not speak of God without starting from man.

And in the theology of Karl Barth, one can and should only speak of man adequately after one has spoken of God and his manifestation in Christ. Only while one speaks of Christ can one according to Barth, speak truly, lovingly and effectively also of man.

In the face of this situation of theology in Germany, the voice of Grundtvig assumes special significance. Especially in the face of the theology of language developed by G. Ebeling and E. Fuchs the entirely different approach of Grundtvig is in my opinion of immediate critical importance. For Grundtvig is far from developing a theology of language and the linguistic epiphany of God as Ebeling and Fuchs have done it. He is in no way concerned with such a thing as God's becoming language through Christ and the paradox that is contained in that statement. For Grundtvig that would be an absurd thought, while, of course, it would be quite on the lines of Kierkegaard's thought.

Just because the affinity of theological thought in Germany with Kierkegaard is so obvious and because Kierkegaard has clearly had a decisive influence on German theology and philosophy, one should also take some notice there of Grundtvig. Kierkegaard's reflections on the dialectics of existence have entered deeply into the history of German thought. Kierkegaard's influence in Germany was often greater than the Germans liked to admit (consider Karl Barth's renunciation of Kierkegaard as his theological teacher). 
There is something of the pathos of Kierkegaard in the Protestant wing of the revolt of the youth in Germany and in the opposition within the Church. Consciously or unconsciously all German criticism of the Church seems somehow affected by the spirit of Kierkegaard's thought. Even the criticism of the current social situation in general is not only inspired by Marx but also clearly influenced by Kierkegaard. The pathos and the "radicality" of the criticism has something of Kierkegaard's criminalistic unmasking of the truth, his break with all prevailing circumstances, his attraction towards the radically different, for the new, for the abolishment of man as he is in our society, for the destruction of the world as it is and the march towards a new one. In this context, Grundtvig constitutes a relevant corrective, especially in the situation as it is today in Germany. That leads us on to the following point.

\section{The inborn and the reborn life of man}

For the German current theological interpretation the inborn human life is the life of the fallen and sinful man. That is Christian common sense. The secular version of the same thing is as follows: that into which we are born is bad, rotten and therefore to be torn right down to the ground. In Christian parlance, the man as he is, is the one that should not be, that should be recreated by God, who has lost his right to be, who is destroying life. The inborn life is doomed from the very start, constitutes the inborn old Adam and must be replaced, through the Word of God by a new Adam. The secular version of this is as follows: the coming new time is the end of what came before, and it is the beginning of a new society.

As far as these thoughts are concerned, Grundtvig is simply in opposition (at least after 1832). But his opposition is quite unknown in Germany, and for that reason it might be of some interest.

Grundtvig thinks of the relation between the new and the old man in a very different way. He does not believe that God or man destroys the old man in order to make room for a new one. Man cannot do that and God will not do that. God does not get rid of the old man, he liberates and frees him, reconciles him with himself, opens him up to God and to his neighbour. God does not make alive by killing. On the contrary: he awakes the dead to life, recon- 
ciles the man who strives within himself and with his neighbours. Man cannot do that, God does it, for the sake of human life. God does not hate the sinner, he loves him and pulls him up to himself. The puzzle for Grundtvig is not about why God does that, it is, how man reacts. God is simple, and so is Christ, but man is unbelievably complex and paradoxical in his reactions. Man is the puzzling thing for Grundtvig, not God.

By reconciling man with himself, God does not reject, he saves man.

God alone knows that puzzle man, and man will not be able to solve it. For man is the puzzle for himself.

It is this puzzle constituted by man that Grundtvig's attention is concentrated upon in his poetry and thought. Who is the man whom God takes pity on? That is Grundtvig's question. Man is God's wonderful creature, made of dust and spirit, with the power and the love and the honesty on his tongue, called to praise his creator, provided with the ability to react spontaneously and freely, made to work, play, and feast.

And yet that same man is also fallen and lost. It is here that the puzzle of the fallen king begins, the puzzle of the destroyer of his own truth and life. Powerless to escape the domination by the creating word of the Creator, unable to do anything against the honesty, truth, love and power of his Creator, he abuses all these things against himself and against his neighbours and against God, turns love into hate, life into death, truth into lies, becomes a stranger to himself. Grundtvig speaks rather of a hidden man than of a hidden God. He is not satisfied to state that man is lost. That only constitutes the problem, not its solution.

For Grundtvig, the inborn and fallen life of man is infinitely instructive and even thrilling. Not that he has an explanation for it up his sleeve or even thinks that such an explanation is so much as possible. It is the insoluble puzzle that arouses his interest. This inborn life has a history, a long life, and by no means a monotonous one. Not all cats are grey for Grundtvig in the night of sin, and the reborn life is not a new beginning out of nothing. The old life is to the new not as nothing to something but as the lost son to the son reunited with his father. It is the same son that is reunited with his father. The son could not be grateful for being accepted again, if he was not the same that had left before. The father has not killed 
his son and created a new one, he has found him again. It is not the son himself that has become altogether somebody else, the purpose and sense of his existence has changed. As we said: the old man is not rejected or even found uninteresting, he is liberated and freed.

In German thought and theology God comes first, and then comes man, while we have heard that Grundtvig's motto was: First man, then a Christian! For Germany, then, Grundtvig might mean a Copernican revolution. For from a human point of view according to the German and Kierkegaard's habit of thought, God is the strange one and the paradox. But sub specie aeternitatis man is himself a stranger, the paradox etc., and he is also the instructive, interesting offender, the source of all the real problems.

This mode of thought is entirely new in Germany, not because one has not been aware in Germany that the reunited son is the lost and sinful son. That has always been maintained. The new and different mode of thought comes, where Grundtvig refuses to justify God's action by reason of men: man and his justification is the problem, not the Godhood of God, his becoming man and his revelation. That is why the hermeneutic problem of how to say the things that are said in the Bible for man today is not of central importance for Grundtvig.

The fascinating aspect of Grundtvig's thought for German theology is obviously not the idea that man is sinful, but that the sinful man is worth our serious interest, that we should appreciate his achievements and his course of life in the history of mankind. It was this interest that brought Grundtvig to take a great interest in the peoples and great figures of history with their myths, cultures, arts, both religious and profane. Grundtvig does not study the pagans to uncover their need for salvation. There one can learn not only about the various forms the evil and dishonesty can take, one can also learn about the good, the true and the beautiful things that are a part of the inborn life.

If these things are talked about in Germany the speaker is suspected of underestimating the power of sin and overestimating man's ability to be good of himself; at the same time one is accused of minimizing the importance of the Gospel, making it superfluous. A view of man such as that expressed by Grundtvig is accused of destroying Christianity by making it a worldly matter. It is argued 
that in this view there is a clear tendency to make the Christian truths available to man by making them a part of this world.

But such criticism overlooks the fact, that Grundtvig's intentions are very different from those suspected by his German critics. Grundtvig's arguments are not directed against the infinite difference between the inborn and the reborn life. His arguments are directed against Christianity perverted by Gnosticism, against the dualism of two different worlds of evil and of good.

Grundtvig is not declaring the sinner a holy man but he is trying to understand him, not just to condemn him. Grundtvig does not see sin as a simple matter of disobedience to God as in the simple, black and white picture painted by the Gnostics. For him, sin is a much more complicated and dialectical matter. Sin for Grundtvig consists in a life-destroying way of thinking and acting about love, honesty (or: truth) and strength. Grundtvig does think that we can learn from the pagans not only how not to be and how not to love, but that one can also benefit much from learning how the pagans do love and live. Conversion of the pagans, for Grundtvig, is not preceded by a complete destruction of the old man. One cannot simply tell the pagan that he is worthless.

For Grundtvig, the decisive step from the inborn life to the reborn life is the re-establishment of man in his relation to God and to his neighbour. This is not a kind of natural theology on the part of Grundtvig: Grundtvig is convinced that man cannot re-establish himself in the way mentioned, he is not predisposed for such a re-establishment. Grundtvig is interested in pagan history because he is interested in the conditions, under which this re-establishment of man can take place. According to him, no one becomes a Christian without having been a pagan first; and no one remains a Christian without being strongly influenced by the spirit and the spirits of paganism. For Grundtvig, this does not lead to a notion of a nation-specific Christianity but to the idea of a constant conflict between Christian and pagan culture. One cannot speak about Christianity without knowing what paganism is.

When pagans are converted by Christians, this is not seen by Grundtvig as a one-way process. Christians have something to give of their own culture, but they also have something to receive and learn. Things different from Christianity can be made conscious to them through their experience with the pagans. 
For the concrete situation in Germany this means that the Christians should and could learn from the pagan movements of our time. But at the same time they have to be careful not to reduce their role to putting a Christian accent on whatever happens to be the fashion at any given time and saying substantially the same thing.

\section{The consequences:}

\section{The theological consequences}

Nothing is true because it is in the Bible. But many things that are true are also in the Bible. Before the book "The New Testament" there comes the viva vox, the life-giving speech of the congregation of the early Christians. Not the Bible but the early congregation is the origin of Christianity. Grundtvig is convinced of this and fights a constant struggle against his own past, in which he advocated the supreme authority of the Bible. This is again an important correction to current views on the authority of the Gospel held among German theologians.

\section{The consequences for the Church system in Germany}

As is well known, the Church system in Germany was and still is one of divisions into Land-Churches, which constitute a kind of parliamentarism in Church matters. These individual Churches have independent status and they enter treaties with the State in which they are treated as quasi-states, and the treaties are of the same sort as the treaties between the Pope and States (concordats). These Churches are committed to certain doctrines and form elaborate bureaucracies.

For this situation, Grundtvig's conception of the Church could turn out as a healthy corrective: for Grundtvig, the Church is not committed to any very specific set of dogmas but constitutes a very free association of believers, with a minimum of bureaucratic organization. In this kind of Church nothing will be accepted as the opinion "of the Church" because some official or other believes it to be true. There are no spokesmen for the Church. "Official" Christianity as practised in Germany is quite out of the question for Grundtvig. For precisely that reason, Grundtvig should be heard today in Germany. In a different way from Kierkegaard he 
could become an important and healthy factor in German Church life.

\section{Consequences for the German "Christian Education"}

I want to finish with a few remarks on Grundtvig's insisting on the need for an educational system, that is independent of Christianity and based on humanitarian ideals. As is well known, Grundtvig is clearly opposed to a Church which strives after political power. For that reason he thinks that education should be a matter of the civic authorities and not of the Church.

The tendency of the Church in Germany at present is exactly in the opposite direction. There it is claimed that Christian education is an inalienable part of Christian responsibility, and that the Church should never give up that responsibility. The German "Grundgesetz" or Constitution demands a Christian synthesis of the educational authorities. There is, then, every reason to take serious note of Grundtvig's educational policies especially under the German conditions I have just outlined. I think we are here concerned with a possible learning process on the part of the Germans, which should perhaps be based on Grundtvig's ideas and could thus do things that are obviously necessary in the particular conditions that prevail in Germany today. 